DOI URL: https://doi.org/10.3126/jbssr.v4i2.29481

\title{
Human Resource Development and Employee Engagement in Nepalese Commercial Banks
}

\author{
Kishor Hakuduwal ${ }^{1}$ \\ Lecturer \\ Bhaktapur Multiple Campus, Tribhuvan University, Nepal
}

\begin{tabular}{l} 
Article History \\
Received 20 Oct 2019 \\
Reviewed 12 Nov 2019 \\
Revised 28 Nov 2019 \\
Accepted 15 Dec 2019 \\
\hline
\end{tabular}

Keywords

career development, employee engagement, human resource development, performance management, training and development

Journal of Business and Social Sciences Research (ISSN: 25422812). Vol IV, No. 2 , December 2019

\begin{abstract}
The objective of the present study is to analyse the impact of human resource development on employee engagement in Nepalese commercial banks by taking three human resource development components of training and development, career development and performance management as independent variables, and employee engagement as a dependent variable. Using the random sampling, 384 employees were selected, and a questionnaire survey was carried out to collect data. Using F-test and t-test, the study found that the training and development, career development and performance management have significant impact on employee engagement in Nepalese commercial banks. The study also revealed that male employees have more emphasis on performance management but female employees have more emphasis on training and development. Likewise, the employees up to the officer level have also more emphasis on performance management but the employees below officer level have more emphasis on training and development.
\end{abstract}

\section{Introduction and Study Objectives}

A planned effort of an organisation to facilitate employee's learning of job-related behaviour, skills, knowledge and attitude is human resource development (HRD). To improve the organizational efficiency and effectiveness enhancing employee's performance, human resource development is essential as continuous process (Baniya, 2004). HRD is a functional necessity for any dynamic and growth-oriented enterprise for the dynamism, competence and effectiveness of its employees. Appraisal system, training, career planning, organisational development,

${ }^{1}$ Dr. Hakuduwal has published a number of research papers in journals. He can be reached at khduwal@gmail.com 
rewards, quality of work life and human resources information are the activities for HRD practice. HRD is the key to skill enhancement of workers for future works in the organisation (Sthapit, 2019).

Armstrong (2014) defined human resource development as distinctive practice which shapes the core competencies that determine how firms compete. A process that builds and enhances the skills, knowledge and attitude of employees is human resource development (CIMA, 2013). Redman and Wilkinson (2006) define that human resource development is related with the development of human competencies throughout time-bound It improves the creative input of people to achieve organisational goals. Nadler and Nadler (1989) focus three activities in human resource development such as (a) training, (b) education and (c) development. To perform the current job more efficiently, training is provided by employers to employees as a learning activity. Education concerns with learning designed to prepare an individual for a job different than the one currently held. Development concentrates the knowledge or skills enhancement in a specified area.

An ability to capture the heads, hearts and souls of employees is employee engagement that is related to instil an intrinsic desire and passion for excellence (Fleming \& Asplund, 2007). It is a positive attitude held by the employee towards the organisation and its values. An engaged employee is aware of the business. Engaged employees work more carefully with colleagues to improve performance within the job for the benefit of the organisation (Robinson et al., 2004). Engaged employees employ and express themselves physically, cognitively, and emotionally during role performance in an organisation (Kahn, 1990). Engaged employees have a connection with work activities. Schaufeli et al. (2002) define employee engagement with three elements. First element is vigour: a high energy level and resilience when working. The second element is absorption: interest in one's work. The last element is dedication; employees experience pride and enthusiasm in their work. Engaged employees care about the future of the organisation. They are sincere in their work as well as loyal too. They are willing to put in extra efforts in their work to ensure that the organisation is led to growth in the industry.

It is said that the performance of the organisation depends on employee engagement. Employee engagement is closely concentrated with human resource development of any organisation. Banking sector is considered as a lucrative sector for work (Nepal Rastra Bank, 2019). Banking sector had to improve the organisational performance through employee engagement.

There is a vital role of the banking sector in the economic development of Nepal. In Nepal, the 28 commercial banks (Nepal Rastra Bank, 2019) are operating which comprise more than $80 \%$ of the assets of banking sectors, that are larger and more complex than other types of financial institutions (Development Banks, Finance Companies and Micro Finance Development Banks). Nepalese 
Commercial banks have provided employment to 33,429 individuals as of midJan 2019 (Nepal Rastra Bank, 2019). Out of them, 79.94 per cent employees are working in the private banks and rest in three public banks (Nepal Bank Limited, Rastriya Banijya Bank Limited and Agricultural Development Bank). The failure of even a single commercial bank can produce contagious effects on the whole financial system (Nepal Rastra Bank, 2019). The human resource of commercial banks should be developed to get the competitive advantage and optimum resource mobilization with employee engagement. Therefore, the objective of the study is to analyse the impact of human resource development in employee engagement of Nepalese commercial banks.

\section{Review of Literature}

Human resource development is a process of developing and unleashing expertise of an employee. The purpose of it is to improve individual, team, work process, and organisational system performance (Swanson \& Elwood, 2009). It is a conscious and continuous process. It increases the knowledge, education and skill of the employee which help in improvement of organisational performance. Chalofsky (1992) mentions human resource development as the practice of increasing the learning capacity of individuals, groups, collectives and organisations. It is related with the application of learning-based interventions for the purpose of optimizing human and organisational growth and effectiveness. DeCenzo and Robbins (1997) identify employee training, management development and career development as major components of HRD. Gomez-Mejia, Balkin and Cardy (2013) specify that four key activities in HRD: training, career development, performance appraisal and performance management. Sthapit (2019) identifies five major components of HRD: training and development, management development, performance management, career development and organisation development.

Employee engagement involves creating prospects for employees to attach with their managers, colleagues and organisations. It covers performance management systems, personal development and growth opportunities, and workplace recreation and remuneration (Mokaya \& Kipyegon, 2014). To superior performance, reduce staff turnover, and improve the well-being of employees, employee engagement is needed (Macey \& Schneider, 2008; Hakanen et al., 2008). Engaged employees' value, enjoy and have pride in their work. They are more willing to help each other and the organisation succeeds.

Sardar et al. (2011), Rashid, Asad and Ashraf (2011) find that there is a significant relationship among employee engagement and decision making / coordination, performance reward systems and employee involvement. They also conclude that training and career development and employee performance appraisals are not significantly related to employee engagement. 
Pandey (2014) depicts that training and development, decentralization and selfmanaged team, information sharing and job security are with organisational performance of the financial sector of Nepal. Sthapit (2014) finds that the Nepalese banks are not strategically mature in their current human resource practices. Pandey (2017) finds that both incidence and intensity of training has a strong effect on organisational performances in Nepalese commercial banks. He also finds that the banks investing primarily in formal training better performed than those relying on informal training. Gnawali (2018) finds that employees training and development programme has positive relationship with organisational performance of Nepal Rastra Bank. In commercial banks of Nepal, there are lots of switches the employees from one bank to another bank (Subedi, 2013). Costs of employee turnover seriously impact on organisational performance and growth (Khadka, 2013). The engaged employees are more productive, creative, loyal, committed and have less absenteeism in Nepalese banking sector (Chhetri, 2017).

\subsection{Training and Development and Employee Engagement}

Employee engagement can be achieved through proper training and development. It is one of the important components of HRD which contributes to employee engagement (Sundaray, 2011). According to Kahn (1990), The employee engagement is highly influenced by intervention from management. HR departments and managers intervene in the working environment of employees mainly through effective communication and strategic training and development to keep constant engagement of employees that improve the organizational performance (Kahn,1990). Jogi and Srivastava (2015) depicts that there is a significant impact of employee development on employee engagement in Indian banking sector.

New recruited and current employees acquire the knowledge and skills to perform their jobs effectively. Training is the one of the best ways for it. The employees who enhance their skills through training are more likely to engage fully in their work. The engaged employee derives satisfaction from grasping new tasks (Swarnalatha \& Prasanna, 2012). Training and development activities are equally important HR functions which are concerned with imparting knowledge and skills for a particular job (Khan, 2013). The opportunities to raise the profile development activities in the organisation can be achieved through training activities. Training and development help the employee to perform their work well. It is useful to reduce the problem of attrition. Training positively predicts employee engagement (Semwal \& Dhyani, 2017). This leads to the first hypothesis.

Hypothesis 1: The training and development has significant impact on employee engagement in Nepalese commercial banks.

\subsection{Career Development and Employee Engagement}

Career development is the series of on-going activities in the organisation. It involves training on new skills, making a career change within an organisation which helps in attracting and retaining the qualified and calibre employees (Kibui 
et al., 2014). Career development is a means of arming employees with skills to perform their jobs. It is the representation of an employer's commitment to their workforce (Alnaqb, 2011). It is important to point out that HR practices work to develop individual knowledge and skills, as well as employee attitude and behaviours.

To attract, develop and retain the employees in the organization, career development is the basic thing (Frederick, 2014). The opportunities for career development play an effective role in employee engagement. Career development is a great way not only to engage employees, but also recognise and motivate them. Organisations with high levels of engagement provide employees with opportunities to develop their abilities and learn new skills. It helps in acquiring new knowledge and realising their potential. It also influences engagement of employees, retaining the most talented employees and providing opportunities for personal development of employees in the organisation (Vazirani, 2007). Deloitte (2017) describes that extensive development opportunities reduces turnover rate of employees. It creates the motivation to employees for engaging in their work for better performance. This forms the basis for the second hypothesis.

Hypothesis 2: The career development has a significant impact on employee engagement in Nepalese commercial banks.

\subsection{Performance Management on Employee Engagement}

Performance management is the process of creating a sound work environment in the organisation. In such an environment, employees are able to perform the job with their best knowledge, skills and abilities. It includes selection of suitable employees, providing effective training and orientation, compensation and recognition system, promotional and career development opportunities to the employees. The overall performance of the organisation can be improved by improving the performance of individuals within a teamwork (Mokaya \& Kipyegon, 2014).

Performance management process creates employee engagement. It encourages managers to have a focus on roles and responsibilities of employees to participate them in the decision-making process. It promotes acceptance of challenging objectives of the organisation in a dynamic business arena. It also recognizes and encourages contributions of employees that exceed expectations. It creates a feeling of being valuable to the organisation that promotes employee engagement (Sundaray, 2011). According to Costello (1994), performance management supports an organisation's overall business goals by linking the work of each individual employee to the overall strategy of the organization. This forms the basis for the third hypothesis.

Hypothesis 3: The performance management has a significant impact on employee engagement in Nepalese commercial banks. 


\section{Research Methods}

To test and analyse the hypotheses, training and development, career development, performance management as independent variables and employee engagement was considered as dependent variables. The study followed the descriptive and analytical research design.

The Cronbach's Alpha was measured to test the reliability of the data. F-test was used to determine the goodness of fit and whether a significant difference exists between the means of the variables under study or not. Regression analysis was used to show the influence of human resource development on employee engagement of Nepalese commercial banks.

Table 1

Number of Sample Employees

Name of Banks

No. of Sample

Employees

Nepal Bank Limited

34

Agricultural Development Bank Limited

Nepal Investment Bank Limited

Nabil Bank Limited

Himalayan Bank Limited

Nepal SBI Bank Limited

Nepal Bangladesh Bank Limited

Nepal Credit and Commerce Bank Limited

NIC Asia Bank Limited

Machhapuchhre Bank Limited

Kumari Bank Limited

Siddhartha Bank Limited

Global Bank Limited

Citizens Bank International Limited

Prime Commercial Bank Limited

NMB Bank Limited

Prabhu Bank Limited

Mega Bank Limited

Century Bank Limited

Sanima Bank Limited

Total

The study used primary data for analysis of the perception of employees on human resource development and employee engagement regarding training and development, performance management and career development. For data collection, a questionnaire was developed and distributed to the employees of banks. All items of questionnaire regarding human resource development and employee engagement were measured on a five-point Likert scale from 1 (strongly 
disagree) to 5 (strongly agree). The demographic profile of respondents such as gender, age, designation, education and job experience are also included in the questionnaire.

The total number of employees working in Nepalese commercial banks is considered as population for the study. The 384 employees as respondents from different commercial banks were randomly selected for the questionnaire survey. The survey was conducted inside the Kathmandu valley and picked the respondents by convenience. Since, the respondents for the questionnaire survey constitute both male and female employees of banks, the sample size is based on gender domain. Therefore, the probability of picking male employee for a questionnaire survey is $p$ (assuming 0.5 ) the probability of selecting a female employee is $1-p=q$, i.e., 0.5 .

Using the above formula, the sample size $\mathbf{n}=\frac{\left(\frac{\mathrm{\alpha}}{2}\right)^{2} * \mathrm{p} * \mathrm{q}}{\delta^{2}}=384$ where, $\boldsymbol{z}$ is the selected critical value of desired confidence level, i.e., $95 \%, \boldsymbol{p}$ is the probability selecting male i.e. $50 \%, \boldsymbol{q}=\mathbf{1 - p}$ and $\boldsymbol{e}=$ error level, i.e., 0.05 .

The multiple regression model of the study are as follows:

$$
\begin{aligned}
& \mathrm{EE}=\beta_{0}+\beta_{1} T D+\beta_{2} C D+\beta_{3} P M+u \\
& \text { Where; } \\
& E E \quad=\text { perception of employees on employee engagement } \\
& T D=\text { perception of employees on training and development } \\
& C D=\text { perception of employees on career development } \\
& P M=\text { perception of employees on performance management } \\
& \beta_{0}=\text { Constant term } \\
& \beta_{1}-\beta_{3}=\text { Coefficients } \\
& u=\text { Error term }
\end{aligned}
$$

\section{Data Analysis and Discussion}

\subsection{Respondents Profile}

The male respondents (65.6 per cent) are higher than female (34.4 per cent). The respondents' below 20 years old, 20 - 30 years old, 31 - 40 years old, and above 50 years old is 1.6 per cent, 41.9 per cent, 33.3 per cent and 23.2 per cent respectively (table 2). The percentage of respondents having Masters' Degree and above is 56 per cent which indicates that most of the employees are working with master level education.

The highest participant is 73.2 per cent from below officer level and rest from up to officer level. The respondents having working experience on banking sector less than 5 years, 5 - 9 years, 10 - 14 years, 15 - 20 years and above 20 years is 28.9 per cent, 33.9 per cent, 13.3 per cent, 8.3 per cent and 15.6 per cent respectively which indicates that the most of respondents participated from fresh group of employees. 
Table 2

Respondents Profile

\begin{tabular}{llll}
\hline Profile & Category & Number of Respondents & Percentage \\
\hline Gender & Male & 252 & 65.6 \\
& Female & 132 & 34.4 \\
Age & Below 20 years old & 6 & 1.6 \\
& 20 - 30 years old & 161 & 41.9 \\
& $31-40$ years old & 128 & 33.3 \\
\multirow{5}{*}{ Educational Qualification } & Above 40 years old & 89 & 23.2 \\
& SLC & 15 & 3.9 \\
& Plus 2 & 32 & 8.3 \\
& Bachelors & 121 & 31.5 \\
Experience & Masters and above & 216 & 56.3 \\
& Less than 5 years & 111 & 28.9 \\
& $5-9$ years & 130 & 33.9 \\
Designation & $10-14$ years & 51 & 13.3 \\
& 15 - 20 years & 32 & 8.3 \\
& Above 20 year & 60 & 15.6 \\
& Up to Officer & 103 & 26.8 \\
\hline
\end{tabular}

Note. Survey, 2019

\subsection{Reliability Test}

The values of Cronbach's Alpha of training and development, career development, performance management and employee engagement are $0.788,0.827,0.868$ and 0.847 respectively (table 3 ). For a reliability test, the value of Cronbach's Alpha of all variables is more than 0.7 which is enough to accept the questionnaire (George \& Mallery, 2009).

Table 3

Reliability Statistics

\begin{tabular}{lll}
\hline Variables & No. of item & Cronbach's Alpha \\
\hline Training and Development (TD) & 5 & 0.788 \\
Career Development (CD) & 5 & 0.827 \\
Performance Management (PM) & 5 & 0.868 \\
Employee Engagement (EE) & 5 & 0.847 \\
\hline
\end{tabular}

\subsection{Multicollinearity}

The tolerance value of all the variables are greater than 0.1 and all variance inflation factor values are less than 10 which indicates that both are in acceptable range (table 4). 
Table 4

Collinearity Statistics

\begin{tabular}{lll}
\hline Variable & Tolerance & Variance Inflation Factor \\
\hline Training and Development, & 0.566 & 1.766 \\
Career Development & 0.539 & 1.854 \\
Performance Management & 0.570 & 1.755 \\
\hline
\end{tabular}

\subsection{Independence or Residuals and Outlier}

The value of Durbin-Watson is 1.972. The independence of residuals assumption does not violate because the value is very close to 2 . Therefore, the outliers have no influence on the regression model.

\subsection{Regression Results}

The value of $\mathrm{R}$ Square 0.616 indicates the dependent variable i.e. employee engagement is explained by variation in independent variables i.e. training and development, career development, performance management by 61.6 per cent (table 5). It means that the employee engagement is explained by variation in other variables by 38.4 per cent.

Table 5

Regression Results

\begin{tabular}{|c|c|c|c|c|c|}
\hline & \multicolumn{2}{|c|}{ Unstandardised Coefficients } & \multirow{2}{*}{$\begin{array}{l}\text { Standardised } \\
\text { Coefficients } \\
\text { Beta }\end{array}$} & \multirow[b]{2}{*}{$t$} & \multirow[b]{2}{*}{ Sig. } \\
\hline & $B$ & Std. Error & & & \\
\hline Constant & 0.586 & 0.123 & & 4.785 & 0.000 \\
\hline Training and Development & 0.247 & 0.042 & 0.249 & 5.900 & 0.000 \\
\hline Career Development & 0.162 & 0.043 & 0.163 & 3.760 & 0.000 \\
\hline \multirow[t]{2}{*}{ Performance Management } & 0.459 & 0.039 & 0.492 & 11.677 & 0.000 \\
\hline & $\begin{array}{l}\text { Sum of } \\
\text { Squares }\end{array}$ & $d f$ & Mean Square & $F$ & Sig. \\
\hline Regression & 136.544 & 3 & 45.515 & 203.215 & 0.000 \\
\hline Residual & 85.110 & 380 & 0.224 & & \\
\hline Total & 221.653 & 383 & & & \\
\hline$R$ & $R$ Square & $\begin{array}{l}\text { Adjusted } R \\
\text { Square }\end{array}$ & \multicolumn{3}{|c|}{ Std. Error of the Estimate } \\
\hline 0.785 & 0.616 & 0.613 & 0.4733 & & \\
\hline
\end{tabular}

Dependent Variable: Employee Engagement

Predictors: (Constant), Training and Development, Career Development, Performance Management 
The sum of square of regression and residual is 136.544 and 85.110 (table 5) respectively and the mean square of regression and residual is 45.515 and 0.224 respectively. The $F$ value of the model is 203.215 with $p$ value $0.000(<0.05)$ indicates that the model is fitted at 5 per cent level of significance.

The $t$ value and $p$ value of training and development is 4.785 and $0.000(0.000$ $<0.05$ ) respectively means training and development is significant at 5 per cent level of significance. So, the alternative hypothesis is accepted i.e. training and development has significant impact on employee engagement.

Similarly, $t$ value of career development is 3.760 and $p$ value is $0.000(0.000$ $>0.05$ ) indicates the career development is significant at 5 per cent level of significance. Therefore, the alternative hypothesis is accepted i.e. career development has significant impact on employee engagement. The beta coefficient and $t$ value of performance management is 0.459 and 11.677 respectively. The $p$ value of performance management is $0.00(0.000<0.05)$ which indicates that the performance management is significant at 5 per cent level of significance. Performance management has a significant impact on employee engagement because the alternative hypothesis is accepted.

From the value of coefficient, it is clear that performance management has the highest positive significance on employee engagement of Nepalese commercial banks followed by training and development and career development.

\subsection{Mean Score}

The male and female employees have reported the importance of the training and development, career development and performance management as HRD for employee engagement indicating mean score of responses more than 3 in all variables.

Table 6.

Mean Score by Gender, Experience and Designation

\begin{tabular}{lllll}
\hline Basis & & $\begin{array}{l}\text { Training and } \\
\text { Development }\end{array}$ & $\begin{array}{l}\text { Performance } \\
\text { Management }\end{array}$ & $\begin{array}{l}\text { Career } \\
\text { Development }\end{array}$ \\
\hline \multirow{2}{*}{ Gender } & Male & 3.38 & 3.39 & 3.10 \\
& Female & 3.44 & 3.32 & 3.21 \\
& Less than 5 years & 3.33 & 3.31 & 3.09 \\
\multirow{3}{*}{ Experience } & $5-9$ years & 3.50 & 3.43 & 3.26 \\
& $10-14$ years & 3.51 & 3.39 & 3.12 \\
& $15-20$ years & 3.42 & 3.32 & 2.92 \\
\multirow{3}{*}{ Designation } & Above 20 year & 3.39 & 3.40 & 3.15 \\
& Up to Officer & 3.33 & 3.34 & 3.10 \\
& Below Officer & 3.45 & 3.39 & 3.17 \\
\hline
\end{tabular}


The highest mean score (3.39) of responses of the male respondent are found for the performance management but the highest mean score (3.44) of responses of the female respondent are found for the training and development (table 6) which indicates that male has more emphasis on performance management and female has more emphasis on training and development. The both male and female employees have less emphasis for career development than training and performance management.

Similarly, the respondent with service experience up to 20 years has more emphasis on training and development but above 20 years' experienced employee emphasis on performance management. The highest mean score (3.34) of responses of the respondent up to officer designation are found for the performance management but the highest mean score (3.45) of responses of the respondent below officer designation are found for the training and development which indicates that respondent up to officer designation has more emphasis on performance management and respondent below officer designation has more emphasis on training and development.

\section{Conclusion and Implications}

The employee engagement involving level of commitment and involvement of an employee is related with the human resource development in an organisation. Human resource development is considered as a key success factor for employee engagement. Therefore, the main focus of the study is to analyse the impact of training and development, career development and performance management on employee engagement in Nepalese commercial banks. The study found that the training and development (Swarnalatha \& Prasanna,2012; Khan, 2013; Semwal \& Dhyani, 2017), career development (Vazirani, 2007; Deloitte,2017), and performance management (Mokaya \& Kipyegon, 2014; Sundaray, 2011; Costello, 1994) has significant impact on employee engagement of Nepalese commercial banks. The study revealed that male employees have more emphasis on performance management but female employees have more emphasis on training and development and same emphasis also found in employees up to officer and below officer designation. The training and development and performance management is more emphasis than career development in Nepalese commercial banks.

Human resource development is a continuous process which imparts skills and knowledge for employees and helps in employee engagement. On the basis of findings of the study, employee engagement through employee training and development, career development opportunities and performance management is significant for Nepalese commercial banks to achieve the competitive advantage in the changing business environment. An effective training and development programmes help the employee to perform their work well and efficiently for better banking performance. The provision for appropriate career development is essential to retain the most talented employees which creates the motivation to employees for engaging their work effectively. A feeling of being valuable to 
the banks is very important to the employees through a sound performance management system. So, human resource development is a crucial part for employee engagement of Nepalese commercial banks.

The findings of the study are implacable for the human resource managers of Nepalese commercial banks in formulating the policies and programmes related with the development of their employees for effective engagement in the job.

The study was mainly confined to perception of employee on human resource development and employee engagement of Nepalese commercial banks. The sample size was based on gender domain. To collect the data, a questionnaire survey was conducted inside the Kathmandu valley and picked the respondents by convenience. Therefore, the findings of the study cannot be generalised to all the financial and non-financial sectors of the country. Further studies could cover other areas than commercial banks by applying more analytical tools than those used in this study.

\section{References}

Alnaqbi, N. (2011). The relationship between human resource practices and employee retention in public organisations: An exploratory study conducted in the United Arab Emirates (Doctoral dissertation). Edith Cowan University.

Armstrong, M. (2014). Strategic human resource management. London: Kogan Page.

Baniya, L. B. (2004). Human resource development practice in Nepalese business organisations: A case study of manufacturing enterprises in Pokhara. The Journal of Nepalese Business Studies, 1(1), 58-68.

Chalofsky, N. (1992). A unifying definition for the human resource development profession. Human Resource Development Quarterly, 3(2), 175-182.

Chhetri, S. (2017). Predictors and outcomes of employee engagement: Empirical study of Nepali employees. Journal of Business and Management Research, 2(1/2), 14-32.

CIMA. (2013). Organisation management and information system. London: Kaplan Publishing.

Costello, S. J. (1994). Effective performance management. New York: Irwin.

DeCenzo, D. A., \& Robbins, S. P. (1997). Personnel/human resource management (3rd ed.). New Delhi: Prentice Hall of India.

Deloitte. (2017). Employee engagement reimagined for higher education [online]. https://www2.deloitte.com/content/dam/Deloitte/us/Documents/human-capital/ushc-employee-engagement-reimagined-higher-education.pdf

Fleming, J. H., \& Asplund, J. (2007). Human sigma: Managing the employee customer encounter. New York: Gallup Press.

Frederick, A. K. (2014). Assessing talent management as a tool for employee retention: A case study of Pro Credit Saving and Loans Limited Kumasi. University of Science and Technology. 
Human Resource Development and Employee Engagement in Nepalese... : Hakuduwal

George, D., \& Mallery, P. (2009). SPSS for windows. Delhi: Pearson Education.

Gnawali, A. (2018). Human resource development practices: Empirical evidence from Nepal Rastra Bank. Kathford Journal of Engineering and Management, 1(1), 5763.

Gomez-Mejia, L.R., Balkin, D.B., \& Cardy, R.L. (2013). Managing human resource $\left(7^{\text {th }}\right.$ ed.). New Delhi: Prentice Hall of India.

Hakanen, J.J., Schaufeli, W., \& Ahola, K. (2008). The job demands-resources model: Three-year cross-lagged study of burnout, depression, commitment, and work engagement. Work \& Stress, 22(3), 224-241.

Jogi, R. A., \& Srivastava, A. K. (2015). Determinants of employee engagement in banking sector: A multivariate study in Central Chhattisgar. Pacific Business Review International, 8(3), 66-70.

Kahn, W. (1990). Psychological conditions of personal engagement and disengagement at work. Academy of Management Journal, 33(4), 692-724.

Khadka, S. (2013). Employee retention in banking industry of Nepal (Doctoral dissertation), Singhania University, India.

Khan, N. (2013). Human resource policies and practices in hospitality industry in India: A case study of selected hotels (Doctoral dissertation). Aligarh Muslim University.

Kibui, A. W., Gachunga, H., \& Namusonge, G. S. (2014). Role of talent management on employees' retention in Kenya: A survey of state corporations in Kenya. International Journal of Science and Research, 3(2), 414-424.

Macey, W., \& Schneider, B. (2008). Engaged in engagement: We are delighted we did it. Industrial and Organisational Psychology, 1, 76-83.

Mokaya, S. O., \& Kipyegon, M. J. (2014). Determinants of employee engagement in the Banking Industry in Kenya: Case of cooperative bank. Journal of Human Resources Management and Labor Studies, 2(2), 187-200.

Nadler, L., \& Nadler, Z. (1989). Developing human resource. San Francisco: JosseyBass Press.

Nepal Rastra Bank. (2019). Bank supervision report 2018. Kathmandu: Author.

Pandey, D. L. (2014). Human resource practices and organisational performance: A comparative study of Nepalese Joint Venture and other financial Institutions (Doctoral dissertation). Tribhuvan University, Nepal.

Pandey, D. L. (2017). Training-performance relationship: A study of Nepalese commercial banks. The Saptagandaki Journal, 8, 31-41.

Rashid, H. A., Asad, A., \& Ashraf, M. M. (2011). Factors persuading employee engagement and linkage of employee engagement to personal \& organisational performance. Interdisciplinary Journal of Contemporary Research in Business, 3(5), 98-108.

Redman, T., \& Wilkinson, A. (2006). Contemporary human resource management: Text and cases $\left(2^{\text {nd }}\right.$ ed. $)$. London, UK: Prentice Hall, Financial Times. 
Robinson, D., Perryman, S., \& Hayday, S. (2004). The drivers of employee engagement. Brighton: Institute for Employment Studies.

Sardar, S., Rehman, A., Yousaf, U., \& Aijaz, A. (2011). Impact of HR practices on employee engagement in banking sector of Pakistan. Interdisciplinary Journal of Contemporary Research in Business, 2(9), 378-389.

Schaufeli, W. B., Salanova, M., González-Romá, V., \& Bakker, A. B. (2002). The measurement of engagement and burnout: A two sample confirmatory factor analytic approach, Journal of Happiness Studies, 3(1), 71-92.

Semwal, M., \& Dhyani, A. (2017). Impact of employees training and career development on their engagement. NICE Journal of Business, 12(1), 87-101.

Sthapit, A. (2014). A strategic perspective on human resource development in Nepal (Doctoral dissertation). Jodhpur National University, India.

Sthapit, A. (2019). Human resource development: Exploring the components beyond traditional taxonomy. Kosh: Annual Issue of Employees Provident Fund, 86, 179188.

Subedi, J. (2013). Causes of attrition of senior level employees: A study on selected commercial banks of Nepal. Banking Journal, 3(2), 37-56.

Sundaray, B. K. (2011). Employee engagement a driver of organisational effectiveness. European Journal of Business and Management, 3(8), 53-59.

Swanson, A. R., \& Elwood, F. H. (2009). Foundation of human resource development ( $2^{\text {nd }}$ ed.), New York, USA: Berrett-Koehler.

Swarnalatha, C., \& Prasanna, T. S. (2012). Employee engagement: A review of literature, Indian Journal of Research, 1(11), 113-116.

Vazirani, N. (2007). Employee engagement (Working paper series (WPS05), SIES College of Management Studies). Retrieved from http://www.siescoms.edu/ images/pdf/reserch/working_papers/employee_engagement.pdf

\section{Funding}

The author received no funding or financial support in carrying out the research.

\section{Conflict of interest}

The author has no conflict of interest in the research work. 